\title{
Connector Pin Device
}

National Cancer Institute

\section{Source}

National Cancer Institute. Connector Pin Device. NCI Thesaurus. Code C50295.

A projecting part of a device that allows it to be secured through an opening. 